Article

\title{
What Is the Customer Value of the Circular Economy? Cross-Industry Exploration of Diverse Values Perceived by Consumers and Business Customers
}

\author{
Leena Aarikka-Stenroos *(D), Martina Don Welathanthri and Valtteri Ranta \\ Unit of Industrial Engineering and Management, University of Tampere, Korkeakoulunkatu 7, \\ 33720 Tampere, Finland; martina.chethanie@gmail.com (M.D.W.); valtteri.ranta@tuni.fi or \\ valtterih.ranta@gmail.com (V.R.) \\ * Correspondence: leena.aarikka-stenroos@tuni.fi
}

check for updates

Citation: Aarikka-Stenroos, L.; Welathanthri, M.D.; Ranta, V. What Is the Customer Value of the Circular Economy? Cross-Industry Exploration of Diverse Values Perceived by Consumers and Business Customers. Sustainability 2021, 13, 13764. https://doi.org/ $10.3390 /$ su132413764

Academic Editors: Arne De Keyser, Katrien Verleye and Simon Hazée

Received: 30 October 2021

Accepted: 8 December 2021

Published: 13 December 2021

Publisher's Note: MDPI stays neutral with regard to jurisdictional claims in published maps and institutional affiliations.

Copyright: (c) 2021 by the authors. Licensee MDPI, Basel, Switzerland. This article is an open access article distributed under the terms and conditions of the Creative Commons Attribution (CC BY) license (https:// creativecommons.org/licenses/by/ $4.0 /)$.

\begin{abstract}
A growing number of companies provide CE products, technologies, services, and solutions, and similarly, an increasing number of researchers have analyzed sustainable and CE business models providing knowledge about $\mathrm{CE}$ technology businesses. However, this research has focused almost solely on the providers' perspective on CE business and offerings, remaining silent on the customer perspective. Therefore, this study contributes by focusing on the customer value of CE innovations and solutions, conducting an explorative qualitative multiple-case investigation among customers of diverse CE businesses, and mapping diverse customer value dimensions, including economic, functional, emotional, and symbolic, and comparing them as perceived by consumer and business customers. The findings show that the functional value of CE offerings dominates. We develop conceptual maps for CE customer value for a theoretical understanding of the CE from the customer perspective and provide insights for managers to assert the value of their CE solutions.
\end{abstract}

Keywords: circular economy; innovation; customer value; business model; qualitative multiple-case study; value dimensions

\section{Introduction}

To enhance the environmental responsibility of technology businesses, much innovation is taking place in sustainability, resource efficiency, and the circular economy (CE). The CE has been increasingly investigated from business and technology perspectives, and research on sustainable business models and CE business is increasing [1,2]. These studies aim to improve our understanding of how innovators and suppliers may turn sustainable offerings into business. However, to apply sustainable technologies and innovations in society and ensure diffusion in markets, such offerings must be adopted and valued by customers, in consumer and business markets. Therefore, it is surprising that researchers have remained silent on the customer value of $\mathrm{CE}$ and sustainable offerings. Understanding the customer value of CE offerings is crucial, as, similar to all innovations, success is determined by how much value the offering can create for customers and stakeholders in the market and society [3]. Thus, understanding the innovation's customer value from the customer's perspective is the crucial part of commercializing innovative solutions [4]. Therefore, this study aims to fill the research gap regarding the customer perspective by focusing on the customer value of CE innovations and solutions.

So far, no focused studies on the customer perspective or customer value of the CE have been conducted. Most CE studies focus on the supplier, seller, and provider perspectives and on business model elements or business practices [2,5,6]. Some studies incidentally discuss some customer-related aspects of the $\mathrm{CE}$, such as drivers of or motivations for choosing recycled, remanufactured, or shared products [7,8] or user adoption of circular offerings $[9,10]$, but do not address customer value per se and contribute to the CE 
literature by building a comprehensive understanding of the value of these offerings for the customer perspective. Thus, this study also aims to show drivers and motivations that direct customer behavior and practices for environmental sustainability. If current practices and the culture of consumption do not change, the $\mathrm{CE}$ will remain a technology-oriented approach that does little to change the current unsustainable economic paradigm [11]. Therefore, by understanding the customer value of the $\mathrm{CE}$, we can also better understand customers' motivations and actions and improve argumentation to encourage consumers and businesses to choose environmentally sustainable $\mathrm{CE}$ offerings and companies to adapt their businesses toward the $\mathrm{CE}$. To create the $\mathrm{CE}$ as a real alternative, managers must understand it sufficiently [12].

Studies indicate that the customer perspective is insufficient in the CE. For example, Kirchherr et al. [13] identified that the consumer and customer perspectives are lacking in CE definitions, and Borrello et al. [14] argue that little is known about consumers' willingness to participate in the CE. Only a few studies acknowledge or indirectly discuss the value circularity or resource efficiency can generate for customers [11,15]. Specifically, empirical investigations among customers of $\mathrm{CE}$ offerings are scarce. Most of the literature on $\mathrm{CE}$ business focuses on the supplier and production side, exploring circular business models [2,5] and strategies for developing circular value propositions [6]. CE businesses aim to generate value from recycling, reuse, and reduction through diverse business models (ranging from using recycled materials and remanufacturing to platforms enabling sharing and product-service systems [2,5,16-21]. However, less attention has been paid to how customers (businesses and consumers) perceive the CE [22,23] (Camacho-Otero et al., 2018; Wastling et al., 2018). Customers are included in diverse CE ecosystems along with other actors of the circular systems [24] (Aarikka-Stenroos et al., 2021) and therefore, should not be neglected. Moreover, Camacho-Otero et al.'s [22] systematic literature review of consumption in the $\mathrm{CE}$ uncovered that most studies focus on specific solutions, such as the sharing economy, product-service systems, and remanufactured products (i.e., the supplier perspective), whereas research on CE consumption is scarce, mostly focusing on consumer acceptance of specific types of products or functions, including barriers, drivers, and motivations of consumer acceptance and adoption. The customer, however, is the central enabler of circular business models [25], and should not be neglected. Scholars and practitioners who exclude the customer perspective and bias a supply-side view regarding CE risk developing business models that are not viable due to a lack of customer demand [26].

The second gap concerns the understanding of the full customer value of the CE. Although understanding the diversified customer value of any technological innovation or solution from the customer perspective determines its commercial success [4], extant studies do not create a complete picture of the full, perceived customer value of CE innovations and solutions. Customer perceived value is considered fundamental to company competitive advantage, and value creation is crucial for customer-supplier relationships and for all economic exchange [27]. Customer value is considered the cornerstone of the consumer and business market, where it is used to assess competitive advantage among offerings [3]. The value dimensions suggested by Rintamäki et al. [28], economic, functional, emotional, and symbolic, can provide a structure for analyzing the full spectrum of customer value in the CE. For example, Korhonen et al. [11] propose three dimensions for benefits of the CE: economic, environmental, and social. However, only some extant studies on the CE and the sharing economy discuss these dimensions, mostly the symbolic or social experience and conception of value in the CE of sustainable offerings $[12,13,22,29,30]$.

To summarize the main research gaps, the customer's perspective of the value of the offered CE innovations, technologies, and solutions remains unclear, as an empirically based understanding of customer value perceptions is missing. The full extent of the diverse customer value of the $\mathrm{CE}$, including diverse aspects beyond economic value, is not understood. Thus, the purpose of the study is to empirically explore the customer value of $\mathrm{CE}$ innovations and solutions, according to diverse customer value dimensions, from 
the customer perspective, in consumer and business markets. In this paper, "consumer (customer)" is used to refer to a person/an individual who purchases or aims to purchase products, or services primarily for personal, family, and household needs, whereas "business customer" refers to more organizational behavior, where the customer is a company (or other types of organization) that makes decisions for the organizational needs and purposes [31]. Two questions guided this research:

1. What is the perceived customer value of CE solutions, specifically economic, symbolic, environmental, and functional value dimensions?

2. What are consumers' and business customers' major perceived determinants of the customer value of CE solutions?

To answer these questions, we build on the existing fragmented and supplier-perspective biased knowledge of CE customer value and conduct a multiple-case study.

The study aims to contribute by putting the customer in the focus and exploring and mapping the customer values, as perceived by the customers themselves. By developing a conceptual model of diverse CE customer value dimensions and related items, the study complements and expands the extant, CE supplier/provider biased research on CE business $[2,5,6,15,21]$. The developed model also aims to generate practical contributions: the identified customer value dimensions and elements can then be exploited by companies who can become more aware of the customer perspective and can then develop and design their CE solutions and communicate their potential benefits for customers in a more informed manner.

The paper is structured as follows: First, as the theoretical background, we discuss extant knowledge on the customer perspective, including motivations and benefits in the $\mathrm{CE}$, and introduce the value dimension approach. Second, we explain our methods for examining consumers' and business customers' value perceptions of critical CE industries and business models. Third, we present the main customer value items from the four value dimensions and discuss the customer value perceptions in consumer and business markets. Fourth, we conclude with our contributions to research and practitioners and suggest further research avenues.

\section{Theoretical Background}

\subsection{Creating Value from CE Innovations and Solutions: The Customer Perspective}

$\mathrm{CE}$ researchers have highlighted the supplier perspective and neglected the customer perspective; thus, there is no understanding of the customer value of CE solutions. Therefore, we briefly review related concepts (e.g., benefits, motivations, and drivers) and approaches (e.g., the sharing economy) to build an initial understanding of the phenomenon.

Benefits gained from CE offerings are one way to conceptualize customer value. Benefits (e.g., cost savings) related to attitude (e.g., satisfaction) were examined in the sharing economy by Möhlmann [32]. While investigating customer value propositions from the CE solution providers' perspective, Ranta et al. [6] found that suppliers' value propositions emphasized intended benefits, such as lower costs, easier usage, increased utility, accessibility to resources, and optimization of value from resources, as well as enhanced customer experiences.

Another strand of research on CE customer value is motivation. Studies have been conducted on motivational triggers and drivers to engage, for example, in recycling $[33,34]$. Diverse motivations, such as critical motivations (distance from the consumption system, ethics, and ecology), economic motivations (gratifying role of price, search for a fair price), and hedonic/recreational motivations (treasure hunting, originality, social contact, nostalgic pleasure), have been found to trigger buying second-hand [35]. For use of car-sharing services, value-seeking, convenience, lifestyle, and environmental motives were identified by Schaefers [36], price, confidence, convenience, and delight orientation by Schallehn et al. [37], and convenience and time savings by Joo [38]. In second-hand business, nostalgia, critical and ethical consumption, quality and durability, and social and familiar relationships (with market actors) were found to be important motivations [39]. 
Yang et al. [40] show that confidence and social benefits have significant and positive effects on commitment in sharing-economy services. The extant research also indicates that quality and satisfaction may play a role in customer value perception. The perceived quality of remanufactured products was found to be a multidimensional construct based on four underlying factors: lifespan, features, performance, and serviceability [8]. Utility, trust, cost savings, quality, community belonging, and familiarity were found to be essential determinants of satisfaction in the sharing economy [32].

Based on extant studies, we assume customer value can be diminished or negative due to inherent characteristics of CE solutions, as sharing and recycling can affect the quality and increase the risk of contamination. Many studies indicated that customers perceive issues and concerns regarding CE offerings: For example, studies have identified fear of unsafeness and contamination from shared products [41], and refurbished products are often rejected as a consequence of a negative trade-off between perceived risks and benefits [42], and concerns about reliability and quality can lower consumer acceptance [10].

Some study results indicated that customer characteristics may play a role in value perceptions in the consumer market. Cervellon et al.'s [43] results for vintage and secondhand customers showed that the main antecedents of vintage consumption are fashion involvement and nostalgia, as well as a need for uniqueness through the mediation of treasure hunting. Eco-consciousness and the thrill of the hunt were found. However, vintage consumers shop for a unique piece with history; second-hand consumers shop for a unique piece at a good price. Another study showed that college students who shopped at second-hand clothing stores are more likely to be environmentally conscious, more sensitive to higher prices, and more likely to wear used clothing to express a vintage look and to be "green". They also perceive used clothing as less contaminated compared to those who do not shop at second-hand clothing stores [44].

Studies on CE business models discuss how companies seek to create value for customers and allow the firm to capture economic value from renewable or recycled alternatives [2,19-21]. In a review of CE business models, Lüdeke-Freund et al. [21] identified six distinct patterns in the $\mathrm{CE}$ business model literature, including repair and maintenance, reuse and redistribution, and refurbishment, and remanufacturing. The main purpose is to retain product value and close resource loops. The other patterns are recycling, cascading and repurposing, and organic feedstock. The main purpose is to retain material value and close resource flows. The authors contended that the patterns can be employed by companies to create value with the $\mathrm{CE}$. However, although customer value is at the core of the business model, the CE business model literature stream has not highlighted what value emerges from these business models for the customer. Several studies from the customer perspective on the value of $\mathrm{CE}$ business models investigated the types of business models where product value is retained (see Wang and Hazen's study [45] on consumer responses to remanufactured products in China), by studies on CE closing-loop business models from the customer perspective are nonexistent. Instead, CE business model research focuses on maintaining the value embedded in materials and products, with a supplier-centric perspective $[2,6,20,21]$

\subsection{Toward a Framework for Exploring Customer Value Dimensions of the $C E$}

To map the full spectrum of the customer value of CE innovations and solutions, we apply Rintamäki et al.'s [28] value dimension approach comprising economic, functional, emotional, and symbolic values. Economic value focuses on the solution's monetary worth and is high in products that have the lowest price or the best trade-off between price and quality; the product's improved quality can be worth the increased price especially in the long run. Functional value can be defined as the perceived utility provided by the solution's functional, utilitarian, or physical performance and is linked to the solution's convenience. Emotional value is derived from the solution's ability to arouse feelings or affective states in the customer, such as inciting enjoyment or a thrill. Finally, symbolic value is derived from the customer's ability to use the solution for self-expression. Solutions with 
symbolic value have meanings beyond their obvious functionality and can, for example, convey the customer as someone who cares about the environment to others [28]. These dimensions have been visible directly and indirectly in extant studies on the CE and the sharing economy.

The results for a sharing economy study suggested that consumer intentions to rent are driven primarily by perceived economic, environmental, and social benefits through the mediator of perceived usefulness, and enjoyment, in turn, driven by a sense of belonging to the sharing community. Interestingly, social influence did not play a role [46]. In a study on the second-hand fashion market, Hwang and Griffiths [47] found some interrelations between hedonic value (close to emotional value) and symbolic value, which indicates that the value dimensions may interact and support each other.

Finally, we summarize the framework before the explorative empirical study: Rintamäki et al.'s [28] model provides a loose but structured framework with four value dimensions. The extant research in recycling, reuse, and sharing provides an initial understanding of what kind of benefits can exist from the customer perspective. This helps identify diverse value items during our exploration which is reported next.

\section{Methodology}

\subsection{Research Design and Data Collection}

We selected an explorative, qualitative research strategy and conducted a qualitative multiple-case study [48] among diverse customers of CE businesses. This research design enabled us to map perceived customer value items in diverse $C E$ businesses and by diverse customers (consumers and business customers) and develop theory through seeking patterns through aggregation and comparison. Therefore, the case sampling followed mostly maximum variation and typical case principles [49]. The aim of the case selection was to include typical business models and offers in CE: The sampling included productand service-focused business models. Particularly the inclusion of platform cases allowed us to approach consumers and business customers in the same case. As food production and construction are industries where most waste is generated [50], we also followed critical case principles [49] and selected cases from these industries. The five CE business cases provided access to ten different customers, representing consumers and business customers (see Table 1).

We collected data from customers using semi-structured interviews with an interview guide [51] to capture and analyze their value perceptions. The interviews were conducted in Northern Europe in 2019-2020. Due to the diversity of CE business and business models, the interviewees held different roles, ranging from buyers to donors (see Table 1). The interviewees for each case were managers and CEOs in the buying/customer organizations (exposing the customer value in the business market) and end-customers (exposing the customer value in the consumer market).

The interview guide had four key sections (the background, decision-making and preferences, CE solution and its use, perceived value, and value dimensions), and it was adjusted to fit the consumer and business customer interviewees. The questions varied from decision-making ("How would you justify the decision to choose the focal firm?") that justifies the values when the purchase decision was made to analysis of value in use ("How does it work now with the offer? How would you describe the benefits/conveniences?"). 
Table 1. Cases and interviewed customers and background information.

\begin{tabular}{cc}
\hline CE Business Case, Industry, and BM & Customer Identifier and Type \\
ResQ Club & Customer 1, Business market customer \\
Dnables companies to sell surplus food to consumers & $\begin{array}{c}\text { Conor/seller of used material/products/surplus } \\
\text { Customer 2, Business market customer }\end{array}$ \\
Industry: Food, grocery, and service & $\begin{array}{c}\text { Donor/seller of used material/products/surplus } \\
\text { Customer 3, Consumer market customer }\end{array}$ \\
Business model: Surplus-selling platforms & Buyer of second-hand/reconditioned/surplus \\
& Customer 4, Consumer market customer \\
& Buyer of second-hand/reconditioned/surplus \\
Netlet Oy Ab & Customer 5, Consumer market customer \\
Enables companies to sell construction surplus & Buyer of second-hand/reconditioned/surplus \\
Industry: Construction & Customer 6, Business market customer \\
Business model: Surplus-selling platforms & Donor/seller of used material/products/surplus \\
Fluid Intelligence Oy & Customer 7, Consumer market customer \\
Business model: Waste management services & Buyer of secondhand/reconditioned/surplus \\
Industry: Waste management & Customer 8, Business market customer \\
Verso Food Oy & Waste management service integrator \\
Industry: Food & Customer 9, Business market customer \\
Gold and Green ${ }^{\circledR}$ & Chooser of alternative sustainable solutions (plant-based protein) \\
Business model: Alternative sustainable solutions &
\end{tabular}

\subsection{Data Analysis}

To ensure that the qualitative study had rigor for theory building, we analyzed the data with Gioia and Pitre's [52] methodology. From the rich data, customer value elements from diverse value dimensions were identified, categorized for consumers and business customers, and condensed into summaries. Then a final model of customer value of $\mathrm{CE}$ innovations and solutions was created. Thus, we also followed Eisenhardt's [53] qualitative analysis techniques by grouping the cases into categories and then analyzing similarities and differences within the group. The analysis was based on a three-level coding process: first-order concepts that express the informants' raw information categorized based on similarities, second-order theoretical themes that explain the phenomena expressed by the first-order categories, and aggregate dimensions when the second-order themes reach theoretical saturation. Figure 1 illustrates the data analysis structure of one customer category. The analysis started by extracting the informants' data from the transcripts of the interviews based on the initial themes; then results from different cases and customer types were compared and synthetized. During this process, empirically expressed customer value perceptions from four dimensions were theorized and developed into a model of customer value domains.

We provide quotations from informants to illustrate general points, improve the transparency of the findings, and improve the study quality. We also applied researcher triangulation [52] to ensure the quality of the interpretative qualitative analysis. 


\begin{tabular}{|lll|}
\hline 1st Order Concepts & 2nd Order Themes & Aggregate Dimensions \\
\hline
\end{tabular}

- Business values and targets: Customer satisfaction through competitive advantage and corresponding profitability.

- Perceived consumer value is monetary- Good quality goods for highly discounted prices.

- Market expansion opportunity by encouraging solution consumers to become full price buyers.

- The quality of our products should be

maintained even with the use of the solution.

- It is a way to promote/market products.

- Use of the solution as a sales tool.

- Bringing in customers, to the new business.

- The solution is another method to reduce waste.

- Solution is the better alternative for disposing

fresh vegitables and breads.

- Uninterruptive Easiness/simplicity on operations resulted from the solution and customer's low expectations on content.

- Fast responsiveness of the solution clearing site for important operations

- Little amount of disposal cost saving. - Less effort (time and resources) than alternatives.

- To earn a bit of money from surplus(50\% of original price).

- Little amount of earnings.

- The solution should not harm the store reputation in misusing the CE purpose.

- It is a way to rescue waste- helps becoming a

sustainable business.

- To avoid harming environment.
- To put surplus in to some use.

\section{- Normal level of waste here is somewhere} between one per cent and one and half per cent of all the turnover we make in, measured in money.

- It's not much. Maybe 5 percent.

- Took over 6 months to decide to purchase.

- However, the solution is not monetarily impressive for grocery.

- Disposal cost save is insignificant and as the

support in site clearance is valued.

- Surplus is donated through the solution.

- Our main target, of course is to reduce the waste to zero so that we order things as much as we sell.

- If the proffessionals fail on prospecting the right demand, the solution is just another method of reducing waste.

- Surplus business does not have a good future in business (at least in grocery) market unless the solutions are much cheaper and complying with the main business stratergy in supplimentary ways other than reducing waste.

- Solutions need to find competitive advantage buy supporting the business goals.
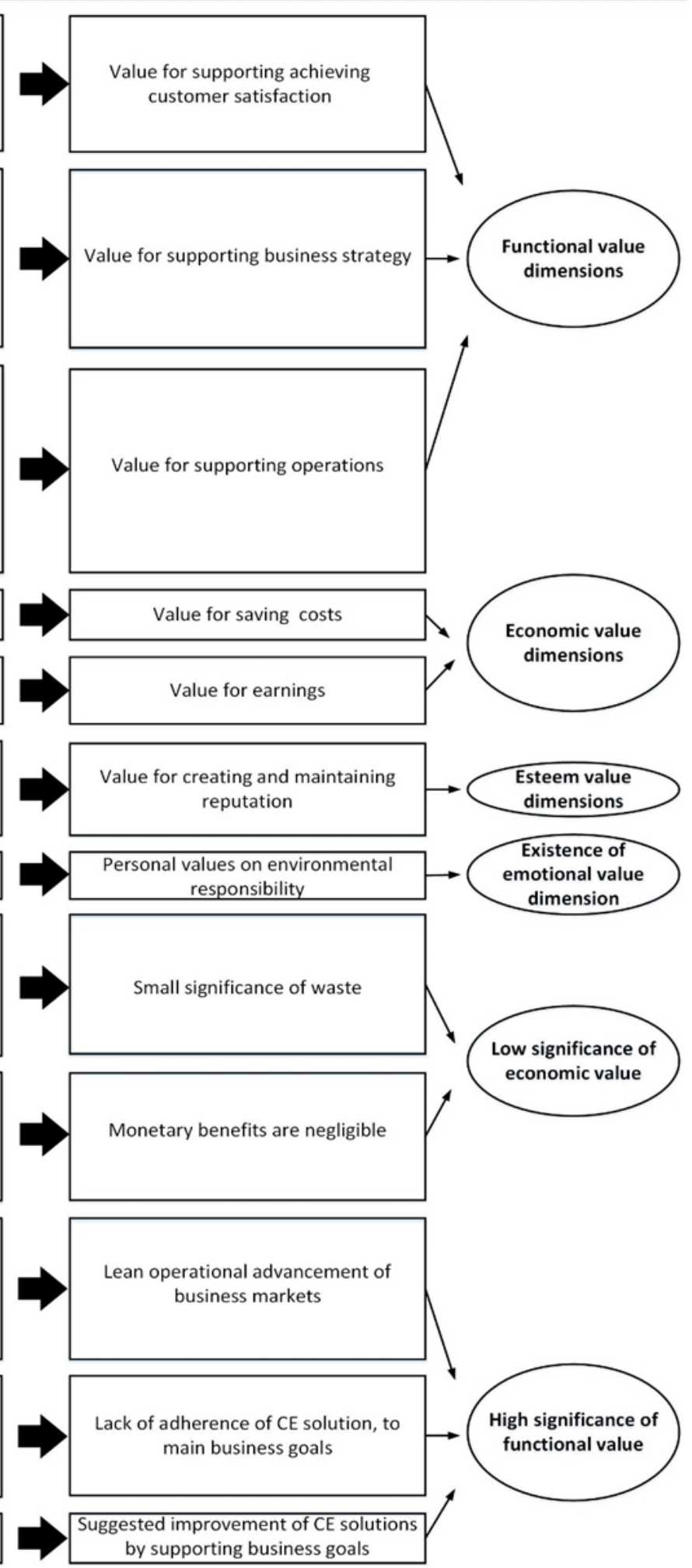

Figure 1. An example of the analysis of one customer category. 


\section{Findings: Customer Value of CE Solutions}

Next, we discuss explorative results for the customer value of $C E$ offerings. We provide an overview of the full spectrum of diverse customer value and then discuss how the four value dimensions occur in business and consumer markets.

\subsection{Overview of CE Customer Value}

The full diversity of CE customer values was uncovered, as we identified customer value items from all four value dimensions (see Table 2) during the full customer journey and all phases, from making purchase decisions and using the solutions to future expectations for the solution. First, the functional value dimension consists of benefits that contribute to business functions and operations (perceived by business customers) and consumer needs and practices (perceived by consumers); they include improved processes and practices. Second, the economic value dimension addresses direct monetary values, such as savings or earnings, as well indirect monetary values that the customers expect and experience in CE solutions. Third, the symbolic/esteem value dimension categorizes the customer value aspects that provide prestige to businesses and individuals. Finally, the emotional values dimension relates to effects that individuals (individuals in companies and as consumers) experience from CE solutions, such as relief or excitement. A key finding is that functional customer values were the strongest and perceived by consumers and business customers from different $\mathrm{CE}$ businesses: They included improved processes, learning, and increased variety and creativity. Another key finding is the diverse, detailed value items for each value dimension that together constitute the full customer value (Table 2).

\subsection{Customer Value of CE Solutions in Business and Consumer Markets}

We discuss the results for $\mathrm{CE}$ customer value for consumer and business markets. All value dimensions (economic, functional, emotional, and symbolic) exist in consumer and business markets, and the functional value dimension dominated both markets. Surprisingly, the emotional dimension was found to be strong in consumer and business markets.

\subsubsection{Customer Value of CE Offerings for Consumers}

Customer values among consumers are illustrated in Figure 2. They originate from consumers buying surplus and recycled materials and products through platforms.

Our analysis of the customer interviews uncovered that consumers highlighted more economic and emotional values, but functional and symbolic/esteem values also existed. Starting with the dominant economic value dimension, consumers were attracted by the low price of the surplus, second-hand, and recycled materials. This was the fundamental characteristic of perceived value in the $\mathrm{CE}$ consumer market. A food waste platform consumer explained economic and other values as follows: "I think of course, it's cheaper, and you might find something that you haven't tried before, but then also I do like the idea of rescuing, reducing food waste". 
Table 2. General patterns of customer values of CE offerings per the four value dimensions, perceived by consumer and business customers.

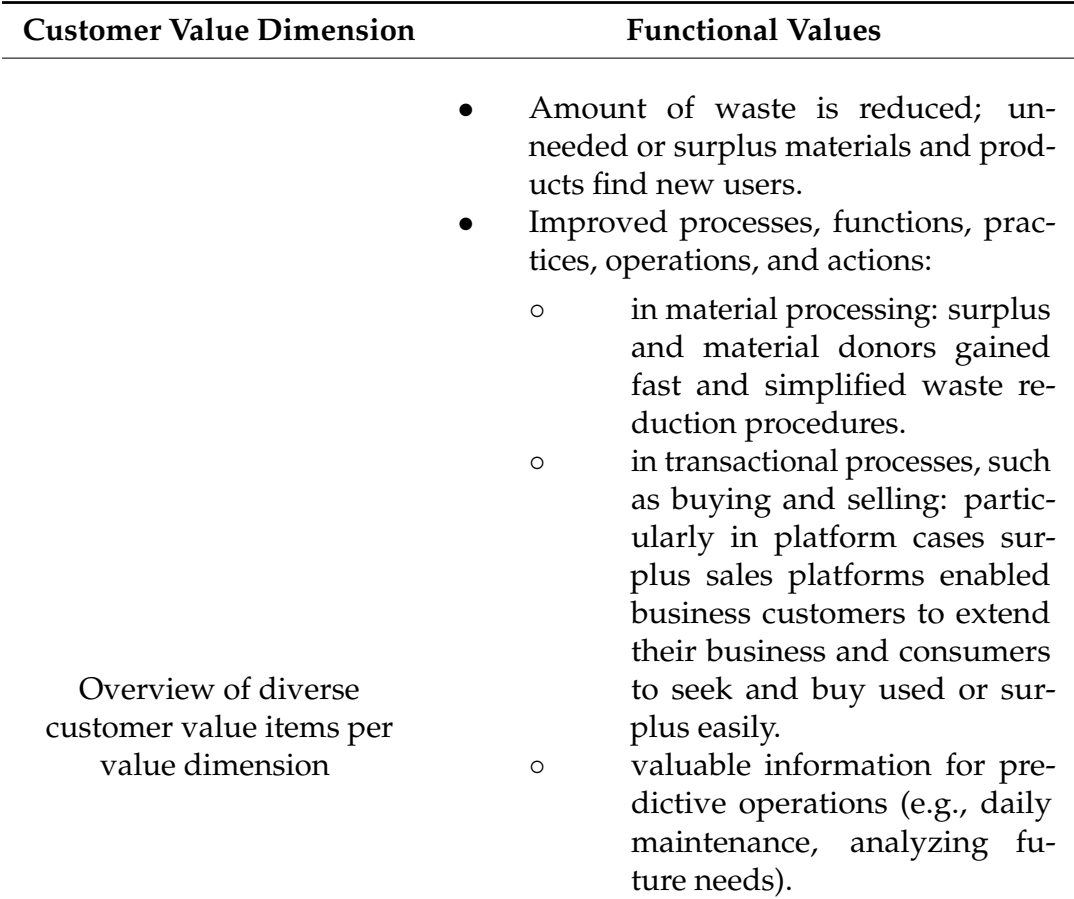

- $\quad$ Fit with practices; easy to use.

- Expansion of variety and options with new and unexpected, even trendy characteristics.

- More information and a better understanding of resource efficiency of own processes enabled learning and predictive operations.

- Innovativeness and creativity (opportunity to try or test something new and unexpected/unconventional, randomness of recycled and surplus nurtures creativity)

\section{Economic Values}

- $\quad$ Direct monetary benefits.

- savings through reduced costs or savings from decreased price attractive discounts.

- direct earnings and increased revenues from secondary/surplus sales from increased market share and new business area.

- Indirect monetary savings due to reduced waste management material, processing, warehousing, logistics, and labor costs.

- Indirect monetary savings from time costs as well psychological and emotional costs (link to functional values; they turn economic values)

- Indirect earnings, e.g., from improved brand value (business customers) or attractive quality-price ratio of surplus/recycled/reused products and materials (consumers and business customers): more and better products with the same money.

Esteem/Symbolic Values

Emotional Values

- Positioning/identity of being sustainable.

- Involvement with others; engagement with similar values.

- Creating new jobs.

- Enabling sustainable growth and new business and start-ups by supporting and being involved in emerging CE business and sustainable development in society.
- Positive emotions:

- $\quad$ Pride (of being involved and behaving in a sustainable way), Relief (about not wasting materials and thus, not harming the environment), Excitement at being involved and of the choice of the recycled/reused/surplus

products and materials.

- Feel of being part of the community.

- Satisfaction related to work or daily actions: business customers, particularly ex perts, felt increased work satisfaction as they could realize their work in more rationale, resource-saving and more sustainable way; consumers enjoyed sustainable everyday practices.

- Negative emotions.

- Inconvenience of recycling and reuse activities, fear of bad quality. 


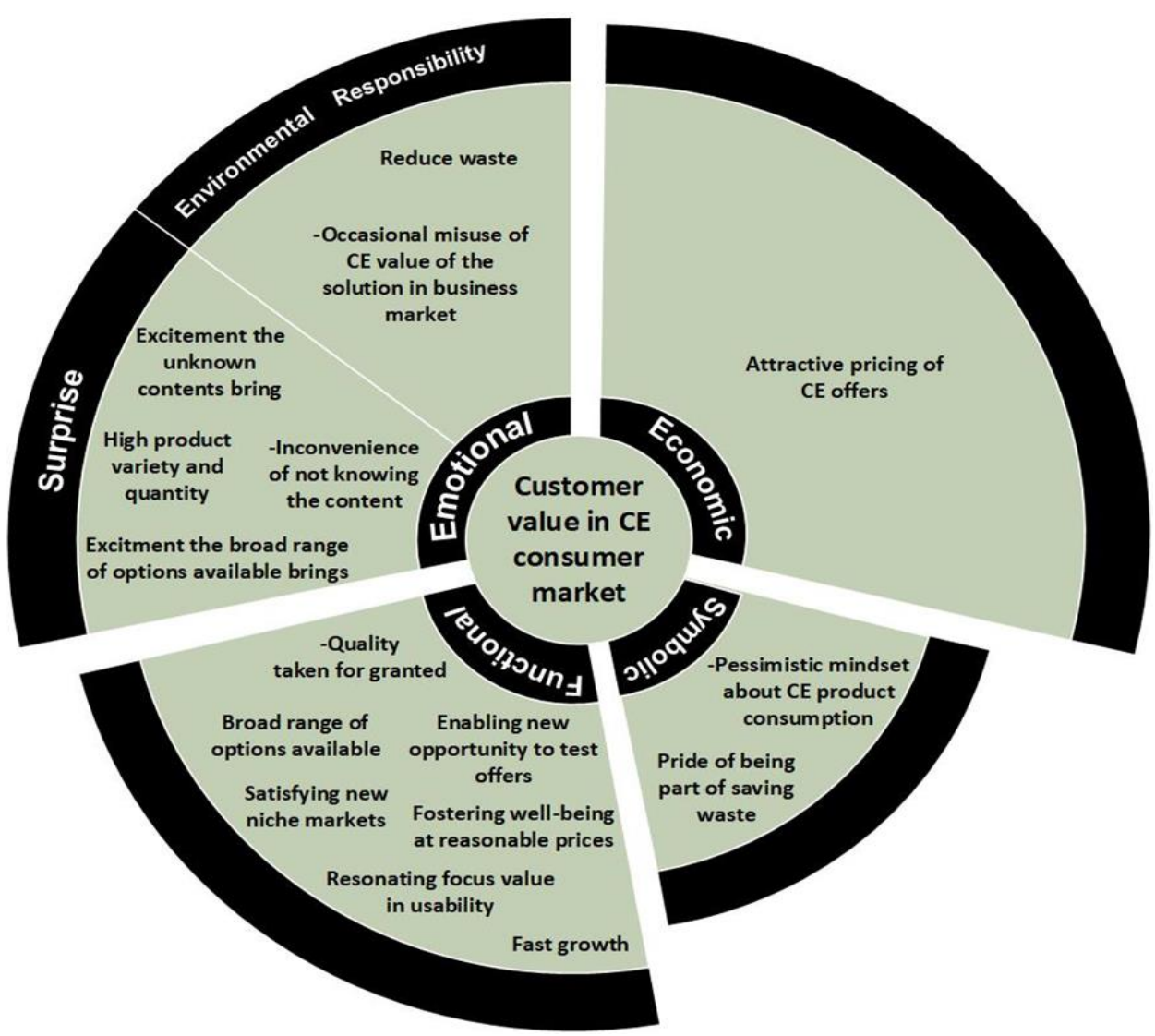

Figure 2. Customer value dimensions of CE solutions perceived by consumer-customerss.

The emotional value dimension occurred through two types of emotional elements, excitement and surprise/variety seeking and relief when experiencing the possibility of contributing to environmental responsibility. For example, surplus food bags with imprecise details, labeled as "surprise food bag" or "a set of pastries", led to consumers" enjoyment of excitement and surprise experiences at product pickup. Emotional relief experienced by being environmentally responsible also generated value for consumers. However, disvalues in the emotional value dimension should also be mentioned: For example, choosy consumers disvalued the ambiguity of the offers' descriptions through platforms due to the possibility of finding disliked content.

The functional value dimension was actualized for consumers as they perceived that they could fulfill their needs easily and conveniently, and have a broad variety of needed products not only with a good price but also that fit their lifestyle and everyday practices. Surplus and recycled offerings gained through platforms, with low pricing and variety, attract certain consumers: For example, the food surplus platform provided good-quality, even healthy, meals conveniently and easily through a digital app service for low-income, highly mobile students. Thus, the solutions carry customer value for satisfying niche markets of students and choosy consumers for healthy food, vegetarians, etc. Many consumers who bought surplus via platform solutions explained that they value the usability aspect of the solutions: They valued up-to-date technology, such as mobile applications and online platforms, making the solutions easy to adapt, use, and practice. Furthermore, consumers argued that the surplus solutions provided the opportunity to try and test new options easily with less risk. For example, via the food waste platform, consumers could test restaurants and meal options before spending on full-price items. This value item concerns decreased risks of high spending. A consumer of a food waste platform/app explained the functional benefits: "I just got from work, and I'm hungry, and 
I need food, so I just check [the food waste platform] if there's any food around-or for a good price-then you just click the buttons and get your food".

Last, the symbolic value dimension represents the values consumers perceive when they experience being prestigious or among smart individuals or communities that contribute to saving the planet. Accordingly, consumers experienced, in addition to emotional value, pride, being role models, and being part of the community in reducing waste.

\subsubsection{Customer Value of CE Offerings by Business Customers}

Figure 3 illustrates how customer value is accounted for in different value dimensions by business customers (by donor/seller of surplus, waste management service integrator, and chooser of alternative sustainable solutions). The business customers perceived customer values in all four value dimensions, but functional and economic values dominated. Further, emotional values clearly existed among business customers. Many businesspeople are oriented toward sustainability, and they experienced, for example, relief from the choice of a more sustainable CE solution. Furthermore, we identified positive and emergent negative values regarding all four dimensions. The prefix (-) indicates the negative values in the dimensions.

The most dominant functional value dimension was manifested in three sub-categories. First, operational functional values were addressed by surplus-selling partners and waste management service integrators. For example, customers who sold their construction surplus through a platform valued the solution as a waste management tool (a more convenient way of clearing surplus from sites) and valued the solution's simplicity to which the operations can easily adapt. The waste management service integrator valued the solution as a performance enhancer of the material, an aid to optimizing machine maintenance, an enabler of useful information channels about machine health, and a material maintenance minimizer. Second, strategic functional values related to companies' business processes were mentioned. For example, surplus-selling customers explained that the surplus platform provided a market expansion opportunity from the platform's wider customer base and a sales tool that accelerated daily sales. The chooser of alternative solutions highly valued the opportunity to act on strategic goals to expand product variety on their shelves. Customer values originating from the function of satisfying customers through improved marketing, branding, and product innovation were found. For example, a surplus-selling customer valued the platform solution as an opportunity to satisfy their focus market's quality requirements by selling good-quality surplus, and thus, maintained the store's reputation for high quality. Moreover, the chooser of alternative sustainable solutions valued the product innovation capability of suppliers with more sustainable offerings in satisfying new markets, as well as the opportunity such start-ups provide in responding to trending consumer demands.

The economic value dimension was the second dominant value among business customers and consists of three types of economic value items: savings, earnings, and solution pricing. Monetary savings were brought up by surplus-selling partners and the waste management service integrator who valued the reduced effort for handling the disposal of the surplus, leading to savings in disposal costs, in addition to saving time spent on the activity. From the waste management service integrator's perspective, the savings were achieved from reduced maintenance labor costs. The construction company explained the benefits of the construction surplus platform service: "Money. This saves our waste management costs [of handling construction surplus as waste]. If I take these tiles to trash, these 14 tonnes would have cost me 2300 euros". 


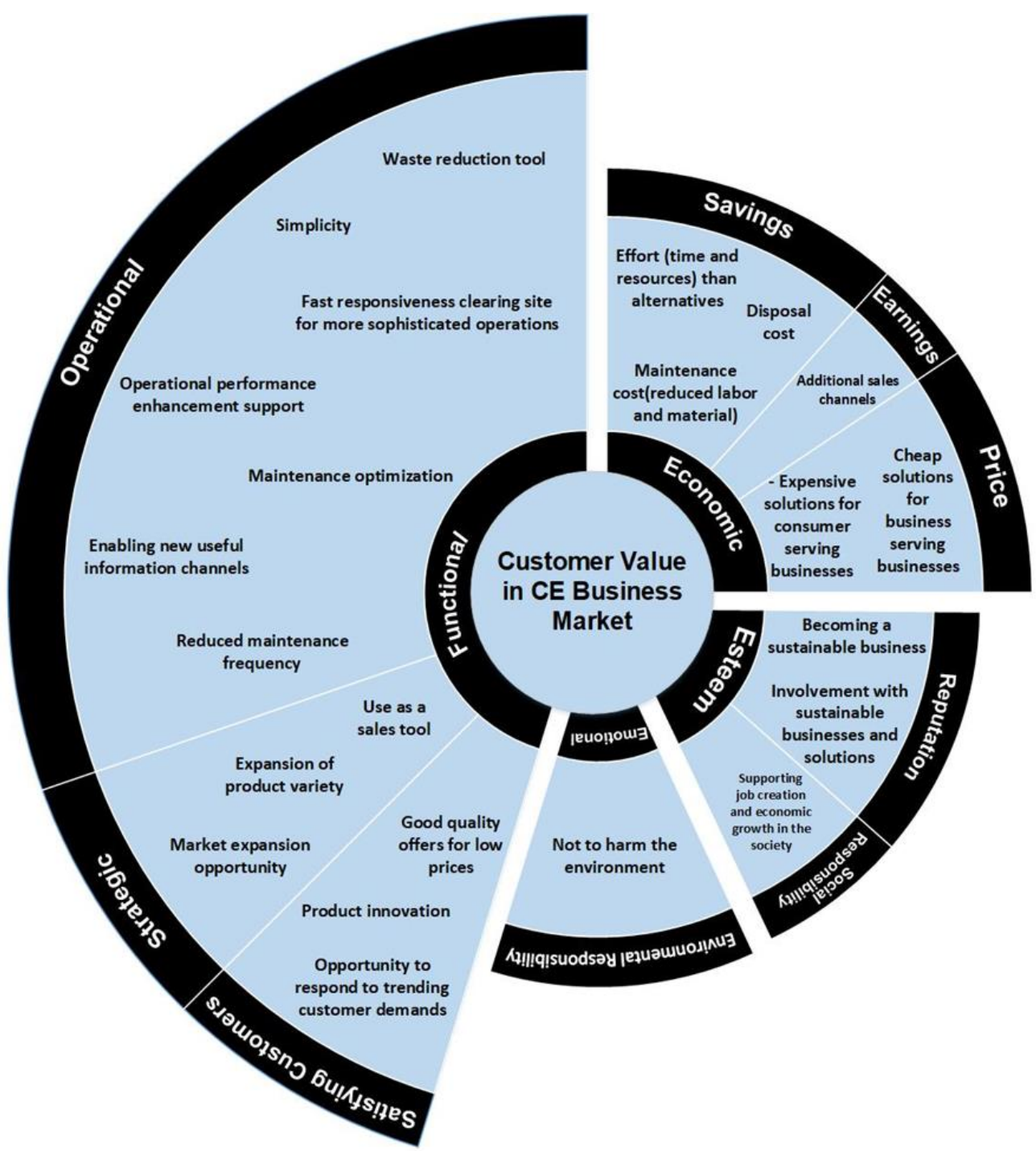

Figure 3. Customer value dimensions of CE solutions perceived by business customers.

Opening up new earnings channels is another important economic value. The increase in earnings was relatively small, compared to the functional value gained, but customers appreciated the ability to generate cash flow compared to previously getting nothing. Furthermore, the pricing of CE solutions was often perceived as attractive in the purchase decision.

For example, a business customer (a café) using the food waste platform service explained how the platform enabled them to reach new consumers, in addition to direct economic and other values:

"It's a good business opportunity that way because a customer can try something [food] she/he otherwise might find a little bit expensive but later think 'it was really good. I'll go there again'. We are not zero [waste] but almost. It's pretty almost every day we sell nearly everything [surplus food] so it's really good. We're a new business so it's bringing new people in. Obviously, a lot of students are using it. Of course, there are lots of people who are thinking very economically and environmental-friendly people, so it brings new customer base in as well, so it has been really good economic- and environment-wise for us. Getting some people in that are not necessarily our primary target group. We get a better reach of customers through ResQ."

The symbolic, esteemed dimension of customer value by business customers was realized through two value-generating items, reputation, and social responsibility. They 
refer to value arising from the prestige that an individual or a business would like to devise, for personal reputation or in the business case, gaining competitive advantage. Thus, business customers value reputation and brand value added by becoming a sustainable business through $\mathrm{CE}$ operations or being involved with a CE business. Moreover, the chooser of alternative sustainable solutions has a social responsibility for creating jobs and supporting the economic growth of society as part of the firm's corporate strategy.

A large retail business customer explained the benefits they gained from being a customer for a company with a more sustainable offering (plant-based, meat-replacement foods):

"When the vegan trend was launched, it was all over the media, and it created pressure, that we need to satisfy our customers' need. [Our retail company] is one of the most responsible stores in the world. So, in our interest is to be able to offer this kind of [meat-reducing] products to our customers. And of course, we do want to support the start-up companies and to create a long-term collaboration. I think it's very important here in Finland to have this kind of companies which creates jobs, and builds up the economy, and enable this environmental aspect as well."

The emotional dimension among business customers was present due to the personal values in the businesses' decision-making. The emotions of environmental responsibility were realized through experiencing positive emotions, such as relief and pride: The value of not harming the environment is strongly voiced by the surplus donors, especially in the construction industry, as conventionally significant amounts of surplus are wasted and disposed of in the environment. However, the platform solution identified users for the surplus, which then generated positive emotions.

\section{Discussion and Conclusions}

\subsection{Developing a Model for CE Customer Value Dimensions}

In this study, we explored diverse perceived values of the $C E$ solutions from the customer perspective. As this literature strand is recent and almost nonexistent, our major contribution is focusing on the customer and mapping empirically customers' value perceptions of $\mathrm{CE}$ offerings. As the key finding from the exploratory research among customers, we identified the spectrum of customer value dimensions and multiple value items. The key findings are developed into a conceptual map in Figure 4 that displays and generalizes the many customer perceived values from functional, economic, emotional, and symbolic dimensions. We identified diverse positive value items from these value dimensions but also negative ones. Another key finding is that we explored which value dimensions play a dominant role and how the value dimensions inter-relate. The CE seems to generate functional value for consumers and business customers through improved practices and operations in addition to the economic value that is supported indirectly by functional and symbolic dimensions (e.g., eased practices save money and costs, or symbolic values generate more earnings). Emotional values were perceived by business customers and consumers. These findings are aligned with and extend the existing knowledge that has identified economic benefits gained from the $\mathrm{CE}$ are among the most relevant determinants in consumer markets pushing the customer toward choosing remanufactured products [42].

As the study's contribution, the conceptual maps for customer value of $\mathrm{CE}$ (Figures 2 and 3, displaying the customer values by business customers and consumers; Figure 4, displaying the generalized customer value map) develop a theoretical understanding of the $C E$ from the customer perspective. As a pragmatic contribution, the map provides insights for managers for asserting the value of their CE solutions. 


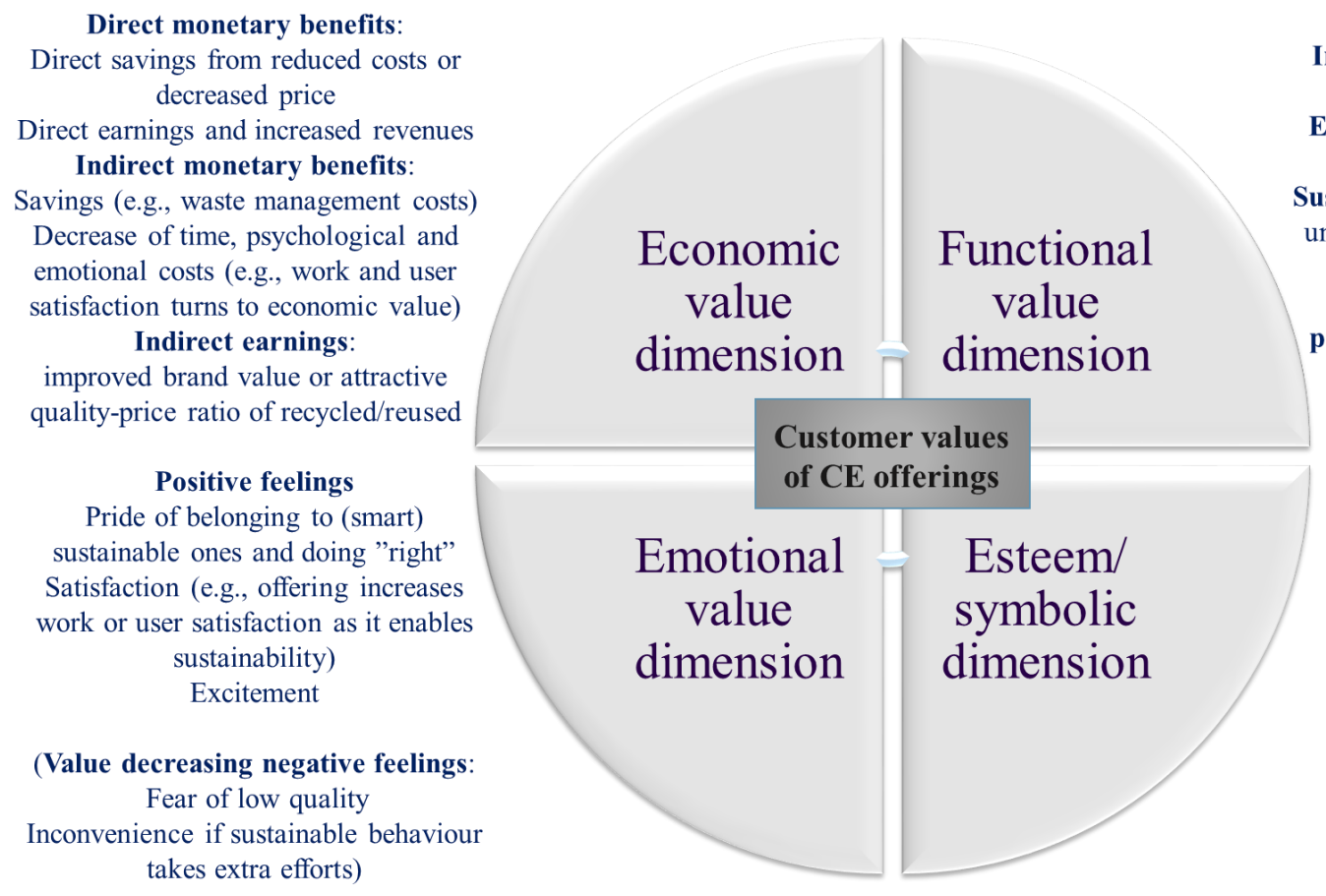

Improved more resource-efficient processes and practices

Extended variety: New options and businesses channels

Sustainable, easy replacement for the unsustainable option: convenient and easy to adopt/use

Better understanding of own

processes and learning to improve regarding resource-efficiency

Positioning among sustainable actors

Manifestation of sustainability business strategies and individual values

Involvement and engagement with other, similar actors

Enabling new, more sustainable (business) environment, market and society via creating jobs and supporting sustainable start-ups

Figure 4. Conceptual model of diverse customer values of CE offerings: four value dimensions and related value items.

The study makes theoretical contributions to several research streams. First, the customer-centric approach and empirical explorative interviews among true customers contribute to the growing literature stream that examines a business approach to the CE $[2,5,6,15,21]$ by focusing on and exploring the customer value of the CE and providing a detailed map of customer value dimensions, in consumer and business markets. Previous CE business researchers focused on primarily economic $[2,5,21]$ and to a lesser extent, environmental value [15] that can be created through CE business models, approaching the issue from the supplier's perspective and perception. By taking the customer perspective, we identified that although economic value plays a role in consumer and business markets, functional value has a dominant role, especially for business customers. For consumers, in addition to economic and functional value, emotional value was important, but not necessarily from emotions emerging from the offerings' environmental sustainability. Instead, the ability to surprise and delight customers, creating a positive customer experience, was perceived as valuable by consumers of CE offerings. This new knowledge of diverse customer values complements CE business research where the company perspective and business model have dominated [21]. As any business model should be grounded on creating customer value [54], this study strengthens the foundation for developing more successful business models for the CE. Some studies on the CE and the sharing economy indirectly discussed customer-focused aspects of the $\mathrm{CE}$, such as motivations and drivers for choosing the $\mathrm{CE}$ solution $[8,14,55]$. We contribute by continuing the discussion focusing on customer value perceived by customers themselves; exploring diverse customer value dimensions in diverse CE business model cases in a structured way, and providing a more comprehensive view of diverse customer value dimensions that extends beyond economic value to other value dimensions.

As implications, the study also provokes discussion on how to make the customer aware of the value potential of CE solutions. As Chamberlin and Boks' work [56] suggests, we need specific CE marketing and promotional practices, to better bring forth customer value and to articulate it better, in an understandable, attractive way [18]. Linking their remarks to these study findings, communication, and messages that explain and clarify negative, value-diminishing aspects of CE offerings (e.g., dispel fears of contamination, prejudice of "dirtiness" or low quality, or lack of "newness" due to circulation) or highlight 
positive, value-creating aspects of CE offerings (e.g., explaining the standardization and quality check processes ensuring that the product is clean and good quality and equal or even better than "new"; or that new CE solutions fit well with existing practices and operations of the customer, or save customers money and effort) are crucial in awaking the diverse sleeping customer value potential. As this study showed that emotional values are perceived by consumers and business customers, effective messages highlighting these values (such as relief or pride) might also be beneficial. The finding regarding the dominant role of functional customer values among consumers and business customers shows the relevance of integrating CE solutions in customers' processes and everyday practices, instead of choosing CE technology and solution push tactics, where products and solutions are typically designed to fit the processes of technological circular material flow [23,57], not customers. Thus, the implication is that to generate optimal customer value, despite acknowledging the requirements of the circular resource flows, designing should also ensure that the CE solution fits well in a value-creating way in customers' operations and practices. This study showed that customers explicitly argued to gain good, even better-quality products in a reasonable price ratio, which confirmed previous findings. Thus, it is crucial to educate customers to acknowledge and identify good quality [22] and how reusing good-quality products or using surpluses of good-quality materials and products generates economic and environmental benefits.

As practical implications from this study, we suggest that the customer value dimensions and elements we identified can be highlighted in sales argumentation and in service/product development, to increase customer value provision. This will accelerate the CE transition and realize more sustainable business growth in multiple sectors and industries. Perhaps one of the most critical key lessons is to make it easy and functional to choose the CE offering. This was perceived as the most valuable among customers and best drives the sustainability transition from the customer perspective, but requires becoming aware of the customer's perspective and value when designing the circular, resource-efficient businesses. The customer value maps (Figures 2-4 and Table 2) we developed also serve as managerial tools that assist in identifying diverse customer perceived value in $\mathrm{CE}$, arguing the value of offerings, adjusting value propositions, and designing new CE solutions to fit with customer value assessments. With these findings for the customer value of CE solutions, technology and business managers can further develop business models and refine value propositions for their solutions.

\subsection{Limitations and Future Research}

The qualitative exploratory research design had several limitations. We analyzed a limited set of cases, customers, and CE businesses. Future research could examine the customer value dimensions in different business settings. The study was conducted in Northern Europe where customers are aware of sustainability issues, and investigations in other global settings could result in different answers. Different global settings and contexts are determined by different social institutions (such as attitudes) that shape customers' and companies' actions, as discussed by Ranta et al. [2]. Camacho-Otero et al. [9] found that buying used, recycled clothing can represent very different meanings in different settings. In some settings, recycled "vintage" clothing indicates trendiness, uniqueness, and a sustainable mindset; in other settings, it is perceived as the only choice of "poor people". Thus, the same circular offering can awake very differing interpretations and value perceptions in different settings. Thus, this investigation reflected European customers' valuations of CE offerings. Selling or buying "surplus food" could be perceived differently in other cultural settings. In addition, different types of business models focus on creating different kinds of value from the supplier perspective [6]. We examined customer value perceptions in various CE business models, but we focused on extreme opposites of cases as regenerative products and platform-based services. We did not cover every business model type identified in the extant research. However, we believe that despite these limitations, the new knowledge developed in this study of CE customer value is useful to 
the global research community and practitioners for understanding why customers choose $\mathrm{CE}$ offerings, thus enabling the transition toward the circular economy.

As future research avenues, first, we encourage more researchers to study the $\mathrm{CE}$ customer perspective, in different cultural contexts, business model settings, and industries. Second, as we showed, the customer perspective is multifaceted, and as the CE often happens in larger value chains and systems engaging multiple customers and other actors from circular ecosystems [24], it would be relevant to study customer value in such broader ecosystems, perceived by different customer or stakeholder types. Our results indicate that one value element (e.g., improved process from "functional" dimension) can increase value perceived on another value dimension (e.g., relief from "emotional" dimension) which is aligned with findings of Hwang and Griffiths [47] and Rintamäki et al. [28]: therefore it would be valuable to examine in a more focused way the dynamics, interaction, and accumulation between value dimensions. Functional value played a key role in the value perceptions of consumers and business customers, exemplified by expectations of improved operational efficiency and convenience. Thus, future studies could focus on how the implementation of digital technologies in CE businesses affects customer value. Extant research suggested that digital technologies improve process efficiency and access convenience [20]. Furthermore, we did not include or analyze the relation of customer awareness and characteristics to value perceptions. Previous studies [45] suggest that information on energy saving, material saving, and emission-reduction positively affected consumers' perceived value and trust in remanufactured products. Therefore, investigating how such information shapes perceived customer value would be relevant.

Author Contributions: Conceptualization, L.A.-S., M.D.W. and V.R.; methodology, M.D.W.; analysis M.D.W. and L.A.-S.; writing—original draft preparation, L.A.-S., M.D.W. and V.R.; writing—review and editing, L.A.-S.; visualization, M.D.W. and L.A.-S.; supervision, L.A.-S. and V.R.; project administration, L.A.-S.; funding acquisition, L.A.-S. All authors have read and agreed to the published version of the manuscript.

Funding: This research was funded by the Strategic Research Council, Academy of Finland through the project entitled "Circular Economy Catalysts: From Innovation to Business Ecosystems" (CICAT2025) (grant ID 320194), and by the European Regional Development Fund through the project entitled "Future circular economy hubs in Finland" (CircHubs) (grant ID A72829).

Institutional Review Board Statement: The study was conducted according to the guidelines of the Declaration of Helsinki and approved by the Institutional Review Board (or Ethics Committee) of Tampere University and the CICAT project.

Informed Consent Statement: Informed consent was obtained from all subjects involved in the study.

Data Availability Statement: Data available on request due to restrictions (to protect privacy of the informants).The data presented in this study are available on request from the corresponding author.

Acknowledgments: An earlier version of this paper was presented at the ISPIM2020 conference to get feedback from the reviewers and conference participants and we thank them for encouraging comments. The paper was excluded from proceedings to enable further publications.

Conflicts of Interest: The authors declare no conflict of interest.

\section{References}

1. Planing, P. Business model innovation in a circular economy reasons for non-acceptance of circular business models. Open J. Bus. Model Innov. 2015, 1, 1-11.

2. Ranta, V.; Aarikka-Stenroos, L.; Mäkinen, S.J. Creating value in the circular economy: A structured multiple-case analysis of business models. J. Clean. Prod. 2018, 201, 988-1000. [CrossRef]

3. Anderson, J.C.; A Narus, J. Business marketing: Understand what customers value. Harv. Bus. Rev. 1998, 76, 53-67. [PubMed]

4. Aarikka-Stenroos, L.; Lehtimäki, T. Commercializing a radical innovation: Probing the way to the market. Ind. Mark. Manag. 2014, 43, 1372-1384. [CrossRef]

5. Urbinati, A.; Chiaroni, D.; Chiesa, V. Towards a new taxonomy of circular economy business models. J. Clean. Prod. 2017, 168, 487-498. [CrossRef] 
6. Ranta, V.; Keränen, J.; Aarikka-Stenroos, L. How B2B suppliers articulate customer value propositions in the circular economy: Four innovation-driven value creation logics. Ind. Mark. Manag. 2020, 87, 291-305. [CrossRef]

7. Armstrong, C.M.; Niinimäki, K.; Kujala, S.; Karell, E.; Lang, C. Sustainable product-service systems for clothing: Exploring consumer perceptions of consumption alternatives in Finland. J. Clean. Prod. 2015, 97, 30-39. [CrossRef]

8. Hazen, B.T.; Boone, C.A.; Wang, Y.; Khor, K.S. Perceived quality of remanufactured products: Construct and measure development. J. Clean. Prod. 2017, 142, 716-726. [CrossRef]

9. Camacho-Otero, J.; Boks, C.; Pettersen, I.N. User acceptance and adoption of circular offerings in the fashion sector: Insights from user-generated online reviews. J. Clean. Prod. 2019, 231, 928-939. [CrossRef]

10. Kuah, A.T.H.; Wang, P. Circular economy and consumer acceptance: An exploratory study in East and Southeast Asia. J. Clean Prod. 2020, 247, 119097. [CrossRef]

11. Korhonen, J.; Honkasalo, A.; Seppälä, J. Circular economy: The concept and its limitations. Ecolog. Econ. 2018, 143, 37-46. [CrossRef]

12. Peronard, J.-P.; Ballantyne, A.G. Broadening the understanding of the role of consumer services in the circular economy: Toward a conceptualization of value creation processes. J. Clean. Prod. 2019, 239, 118010. [CrossRef]

13. Kirchherr, J.; Reike, D.; Hekkert, M. Conceptualizing the circular economy: An analysis of 114 definitions. Resour. Conserv. Recycl. 2017, 127, 221-232. [CrossRef]

14. Borrello, M.; Caracciolo, F.; Lombardi, A.; Pascucci, S.; Cembalo, L. Consumers' perspective on Circular Economy Strategy for Reducing Food Waste. Sustainability 2017, 9, 141. [CrossRef]

15. Antikainen, M.; Lammi, M.; Hakanen, T. Consumer service innovation in a circular economy-the customer value perspective. J. Serv. 2018, 3, 1-8.

16. Tukker, A. Product services for a resource-efficient and circular economy-A review. J. Clean. Prod. 2015, 97, 76-91. [CrossRef]

17. Esposito, M.; Tse, T.; Soufani, K. Introducing a Circular Economy: New Thinking with New Managerial and Policy Implications. Calif. Manag. Rev. 2018, 60, 5-19. [CrossRef]

18. Lieder, M.; Asif, F.M.; Rashid, A.; Mihelič, A.; Kotnik, S. A conjoint analysis of circular economy value propositions for consumers: Using "washing machines in Stockholm" as a case study. J. Clean. Prod. 2018, 172, 264-273. [CrossRef]

19. Nußholz, J.L.K. A circular business model mapping tool for creating value from prolonged product lifetime and closed material loops. J. Clean. Prod. 2018, 197, 185-194. [CrossRef]

20. de Sousa Jabbour, A.B.L.; Rojas Luiz, J.V.; Rojas Luiz, O.; Jabbour, C.J.C.; Ndubisi, N.O.; Caldeira de Oliveira, J.H.; Junior, F.H. Circular economy business models and operations management. J. Clean. Prod. 2019, 235, 1525-1539. [CrossRef]

21. Lüdeke-Freund, F.; Gold, S.; Bocken, N.M.P. A Review and Typology of Circular Economy Business Model Patterns. J. Ind. Ecol. 2018, 23, 36-61. [CrossRef]

22. Camacho-Otero, J.; Boks, C.; Pettersen, I.N. Consumption in the Circular Economy: A Literature Review. Sustainability 2018, 10, 2758. [CrossRef]

23. Wastling, T.; Charnley, F.; Moreno, M. Design for Circular Behaviour: Considering Users in a Circular Economy. Sustainability 2018, 10, 1743. [CrossRef]

24. Aarikka-Stenroos, L.; Ritala, P.; Thomas, L.D.W. Circular economy ecosystems: A typology, definitions, and implications. In Handbook of Sustainability Agency; Teerikangas, S., Onkila, T., Koistinen, K., Mäkelä, M., Eds.; Edward Elgar Publishing: Cheltenham, UK, 2021; pp. 15-37, in press.

25. Gallaud, D.; Laperche, B. Circular Economy, Industrial Ecology and Short Supply Chain; John Wiley \& Sons: Hoboken, NJ, USA, 2016.

26. Repo, P.; Anttonen, M. Emerging consumer perspectives on circular economy. In Proceedings of the 13th Nordic Environmental Social Science Conference HopefulNESS, Tampere, Finland, 6-8 June 2017.

27. Aarikka-Stenroos, L.; Jaakkola, E. Value co-creation in knowledge intensive business services: A dyadic perspective on the joint problem solving process. Ind. Mark. Manag. 2012, 41, 15-26. [CrossRef]

28. Rintamäki, T.; Kuusela, H.; Mitronen, L. Identifying competitive customer value propositions in retailing. Manag. Serv. Qual. Int. J. 2007, 17, 621-634. [CrossRef]

29. Santamaria, L.; Escobar-Tello, C.; Ross, T. Switch the channel: Using cultural codes for designing and positioning sustainable products and services for mainstream audiences. J. Clean. Prod. 2016, 123, 16-27. [CrossRef]

30. Hobson, K.; Lynch, N.; Lilley, D.; Smalley, G. Systems of practice and the Circular Economy: Transforming mobile phone product service systems. Environ. Innov. Soc. Transit. 2018, 26, 147-157. [CrossRef]

31. Kotler, P.; Armstrong, G. Principles of Marketing, 18th ed.; Pearson: London, UK, 2020.

32. Möhlmann, M. Collaborative consumption: Determinants of satisfaction and the likelihood of using a sharing economy option again. J. Consum. Behav. 2015, 14, 193-207. [CrossRef]

33. Bagozzi, R.P.; Dabholkar, P.A. Consumer recycling goals and their effect on decisions to recycle: A means-end chain analysis. Psychol. Mark. 1994, 11, 313-340. [CrossRef]

34. Park, J.; Ha, S. Understanding Consumer Recycling Behavior: Combining the Theory of Planned Behavior and the Norm Activation Model. Fam. Consum. Sci. Res. J. 2014, 42, 278-291. [CrossRef]

35. Guiot, D.; Roux, D. A Second-hand Shoppers' Motivation Scale: Antecedents, Consequences, and Implications for Retailers. J. Retail. 2010, 86, 355-371. [CrossRef] 
36. Schaefers, T. Exploring carsharing usage motives: A hierarchical means-end chain analysis. Transp. Res. Part A Policy Pract. 2013, 47, 69-77. [CrossRef]

37. Schallehn, H.; Seuring, S.; Strähle, J.; Freise, M. Customer experience creation for after-use products: A product-service systemsbased review. J. Clean. Prod. 2019, 210, 929-944. [CrossRef]

38. Joo, J. Motivations for Participating in Sharing Economy: Intentions to Use Car Sharing Services. J. Distrib. Sci. 2017, 15, 21-26. [CrossRef]

39. Machado, M.A.D.; Almeida, S.O.; Bollick, L.C.; Bragagnolo, G. Second-hand fashion market: Consumer role in circular economy. J. Fash. Mark. Manag. Int. J. 2019, 23, 382-395. [CrossRef]

40. Yang, S.; Song, Y.; Chen, S.; Xia, X. Why are customers loyal in sharing-economy services? A relational benefits perspective. J. Serv. Mark. 2017, 31, 48-62. [CrossRef]

41. Catulli, M.; Cook, M.; Potter, S. Consuming use orientated product service systems: A consumer culture theory perspective. J. Clean. Prod. 2017, 141, 1186-1193. [CrossRef]

42. van Weelden, E.; Mugge, R.; Bakker, C. Paving the way towards circular consumption: Exploring consumer acceptance of refurbished mobile phones in the Dutch market. J. Clean. Prod. 2016, 113, 743-754. [CrossRef]

43. Cervellon, M.C.; Carey, L.; Harms, T. Something old, something used: Determinants of women's purchase of vintage fashion vs second-hand fashion. Int. J. Ret. Distrib. Manag. 2012, 40, 956-974. [CrossRef]

44. Yan, R.N.; Bae, S.Y.; Xu, H. Second-hand clothing shopping among college students: The role of psychographic characteristics Young Consum. 2015, 16, 85-98. [CrossRef]

45. Wang, Y.; Hazen, B. Consumer product knowledge and intention to purchase remanufactured products. Int. J. Prod. Econ. 2016, 181, 460-469. [CrossRef]

46. Barnes, S.; Mattsson, J. Understanding collaborative consumption: Test of a theoretical model. Technol. Forecast. Soc. Chang. 2017 118, 281-292. [CrossRef]

47. Hwang, J.; Griffiths, M.A. Share more, drive less: Millennials value perception and behavioral intent in using collaborative consumption services. J. Consum. Mark. 2017, 34, 132-146. [CrossRef]

48. Yin, R.K. Case Study Research and Applications: Design and Methods; SAGE Publications, Inc.: Thousand Oaks, CA, USA, 2017.

49. Patton, M.Q. Qualitative Evaluation and Research Methods; SAGE Publications, Inc.: Thousand Oaks, CA, USA, 2002.

50. The European Commission, Directorate-General for Environment. Links between production, the environment and environmental policy. Summary Report. In EU Commission Report; Contract ENV.F.1/FRA/2014/0063; Publications Office of the European Union: Luxembourg, 2019.

51. Flick, U. Semi-structured interviews. In An Introduction to Qualitative Research; SAGE Publications: New York, NY, USA, 2002; pp. 74-95.

52. Flick, U. Triangulation in qualitative research. In A Companion to Qualitative Research; Flick, U., Von Kardoff, E., Steinke, I., Eds.; SAGE Publications: New York, NY, USA, 2004; pp. 178-183.

53. Gioia, D.A.; Pitre, E. Multiparadigm perspectives on theory building. Acad. Manag. Rev. 1990, 15, 584-602. [CrossRef]

54. Teece, D.J. Business models, business strategy and innovation. Long Range Plan. 2010, 43, 172-194. [CrossRef]

55. Wang, Y.; Wiegerinck, V.; Krikke, H.; Zhang, H. Understanding the purchase intention towards remanufactured product in closed-loop supply chains: An empirical study in China. Int. J. Phys. Distrib. Logist. Manag. 2013, 43, 866-888. [CrossRef]

56. Chamberlin, L.; Boks, C. Marketing Approaches for a Circular Economy: Using Design Frameworks to Interpret Online Communications. Sustainability 2018, 10, 2070. [CrossRef]

57. Codini, A.P.; Bertoli, G.; Frassine, R. Ecodesign strategies and customer value: A conjoint approach. In Customer Satisfaction and Sustainability Initiatives in the Fourth Industrial Revolution; Silvestri, C., Piccarozzi, M., Aquilani, B., Eds.; IGI Global, Busi-ness Science Reference: Hershey, PA, USA, 2020; pp. 189-211. 